エキシマ・ダイ・レーザーを用いた組織内光線力学的 治療効果

\title{
Effect of Photodynamic Therapy Using Excimer Dye Laser
}

○酒井治正，會沢勝夫, ${ }^{*}$ 加藤治文，小中千守，河手典彦，西宮克明， 斉藤 誠, 木下孔明，野口正之，早田義博

OHarumasa Sakai, Katsuo Aizawa, Harubumi Kato, Chimori Konaka, Norihiko Kawate, Katsuaki Nishimiya, Makoto Saito, Komei Kinoshita, Masayuki Noguchi, Yoshihiro Hayata

東京医科大学外科, 同第 2 生理 ${ }^{*}$

Dept. of Surgery Tokyo Medical College

Dept. of Physiology Tokyo Medical College ${ }^{*}$

\section{ABSTRACT}

Various basic and clinical studies have been performed concerning photodynamic therapy (PDT) with hematoporphyrin derivative (PDT). Up to the present argon dye lasers have been used as an excitaion sourse for HpD. Argon dye laser emits a continuous wave beam. Recently we have been using an excimer dye laser which emits a pulse laser beam. It is generally accepted that PDT performed with continuous wave light (E.G. an argon dye laser) results in necrotic changes in tumor tissue up to depth of $5 \mathrm{~mm}$. In this experiment we obtained necrotic changes up to about $10-15 \mathrm{~mm}$ in depth in mouse breast cancer tumor with the excimer dye laser.

1.はじめに

ヘマトポルフィリン誘導体 $(\mathrm{HpD})$ を用いた光線 力学的治療 (Photodynamic therapy ; PDT) につ いて数多くの研究，報告がなされている。現在， 悪性腫晹治療に際して, HpDの励起光源として $630 \mathrm{~nm}$ のアルゴン・ダイ・レーザーが使われてい る。我々はより強い殺細胞効果を得る為, 連続光 であるアルゴン・ダイ・レーザーにかわって，パ ルス光であるエキシマ・ダイ・レーザーを使用し，
励起光源の違いによる，PDT効果の差について 基礎实験を行った。

以前より，投与した HpDの量, 方法, 励起光照 射条件が等しいのにもかかわらず，PDT 効果に バラッキのある事は，多くの人々によって指摘さ れてきた。我々は，エキシマ・ダイ・レーザーを 使用した顕微分光測光を行なら事により，腫瘦内 に打忷る $\mathrm{HpD}$ 分布状態を測定し, PDT 効果 の差に及ぼす要因の一つの究明を試みた。 
2. 方 法

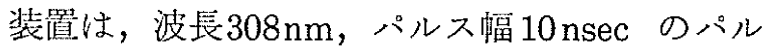
ス光を発する浜松フォトニクス社製のキセノンク ロライドガス封入ェキシマ・レーザーC1891 を色 素励起光源として使用した。これを Rodamineに よる色素装置を使い，波長 $630 \mathrm{~nm} ， ハ ゚ ル ス$ 幅 10 nsec，I パルス $1.54 \mathrm{~mJ}, 3.75 \mathrm{~Hz}$ のパルス光を得 た。(Fig 1)

対象はFM系自然発症乳癌マウス，级びマウス 腎細胞起源の mKS-A 細胞を RPMI-1640培地て培 荃し細胞 $1 \times 10^{7}$ 個を週令 3 週のBALB/C マウス 背面皮下に移植したものを使用した。

それぞれに HpD 50 mg/ $\mathrm{kg}$ を腹腔内投与し，6時 間後，エーテル麻酔を行ない， $3.75 \mathrm{~Hz}, 10$ 分間 の照射を剃毛した腫痬部に皮䖉上より行なった。

照射後ただちに腫瘳を摘出し，ホルマリン固定 した後，H一E染色，顕微鏡的検索を行なった。マ ウス実験腫痬内に拈ける $\mathrm{HpD}$ 取り达父分布に対 する実験では，HpD $50 \mathrm{mg} / \mathrm{kg}$ を腹腔内投与し， その後13ないし14 時間後に腫瘰摘出を行なった。 摘出腫晹の迅速凍結切片を作製し，腫湯標本を $1 \times$ $1 な い し 2 \times 2 \mathrm{~cm}$ の分画に分け，各分画について萤 光顕徽鏡で监光を観察すると共に，高速顕微絑光 分光測光計を使用して蛍光 線を求めた。䖺光曲 線より $615 \mathrm{~nm}$ から $645 \mathrm{~nm}$ の範囲の area 計算を行 ない，その値の比をもって，各分画に含まれる $\mathrm{HpD}$ の相対量とし，腫瘍内に抢ける $\mathrm{HpD}$ 分布状 態を観察した。

相対蛍光量はFig 8 のごとく5段階に分け，各 分画每識別してその分布状態を钼察した。

3. 結果

Fig 2. 3 FM系自然発症乳癌に照射した後の H E染色した標本である。照射光は上方ょり下方に 向かっているが，入射光に一致した堎死変化が認 められ，厚さ $8 \mathrm{~mm} の$ 腫湯下部まで完全に貫通して いる事がわかる。又レーザー光の光路よりはずれ ている所には変化が認められていない。

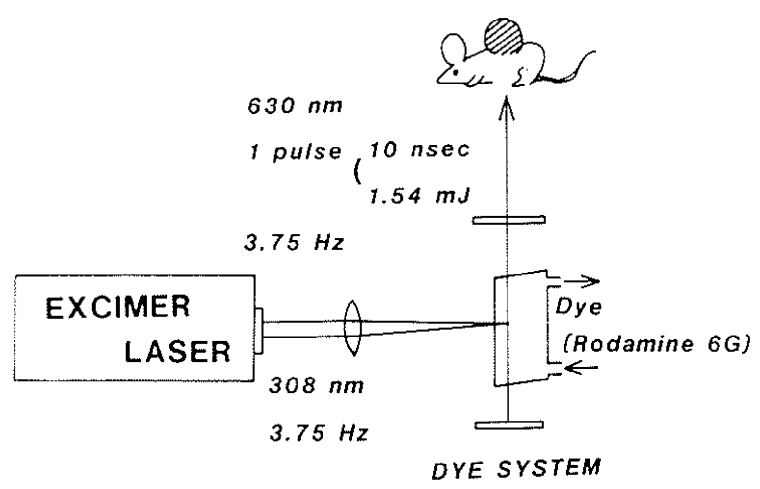

Fig 1

Fig 4.5 同様にFM系自然発症乳癌に対し， 左上方より2ケ所照射したものである。光照射部位 に一致した壊死変化が認められ，PDT効果 が， 深さ10mm に達している事がわかる。

Fig 6.7 自然発症乳癌に上方より照射したも のであるが，これでは非常に良い深速度が得られ 最大 15 mmにまでPDT 効果が達している。

以上の様にFM 系自然発症乳癌では，非常に良 いPDT効果 が得られたが， mKS-A 細胞移植 BALB/cmouse では，壊死変化に非常なバラッキ があり，臣とんど填死変化が認められないものも あった。

そこで $\mathrm{mKS}-\mathrm{A}$ 細胞移植マウス腫痬の $\mathrm{HpD}$ 顕 微蛍光測定を行った。Fig 8 のごとく相対蛍光量 を分画ごとに測定すると，Fig 9.10 の結果を得 た。図より明らかな樣に，同一瘇痬内で，HpDの 分布に非常なバラッキが見られ，HpD が存在し ない部位もかなり広範囲に認められる。

4. 考察

エキシマ・ダイ・レーザーを使用したPDTに揖 いては，最大 $15 \mathrm{~mm} ，$ 多くの場合約 $10 \mathrm{~mm}$ では壊 死変化が認められ，連続光の効果が約 $5 \mathrm{~mm}$ と言わ れてきたのに比べ，明らかにすぐれていると考光 られる。これは HpDが版起一重項状態より，無輻 射的に三重項状態となり，そのエネルギーによっ て Sing let oxygen が産生され，殺細胞効果を示 すと考えられている事から, 又, $\mathrm{HpD} 1$ 分子を励 


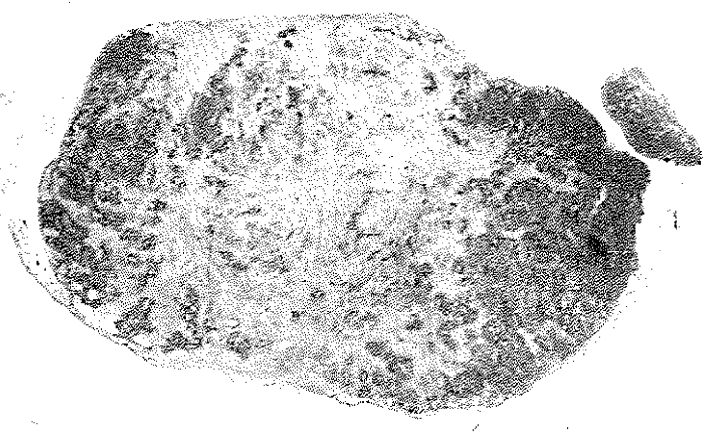

Fig 2

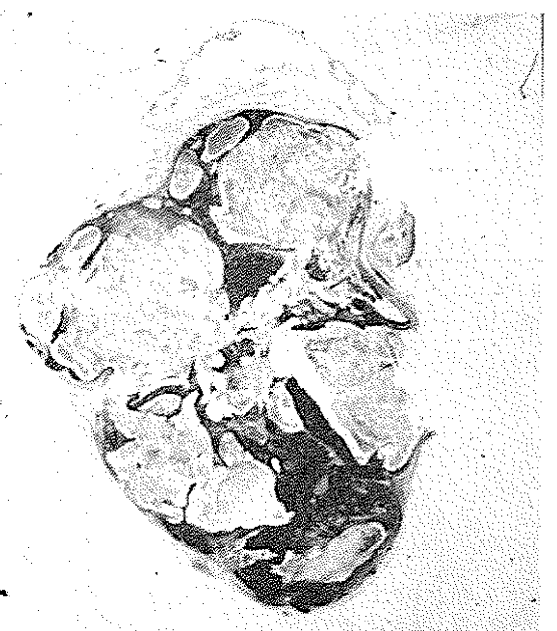

Fig 4

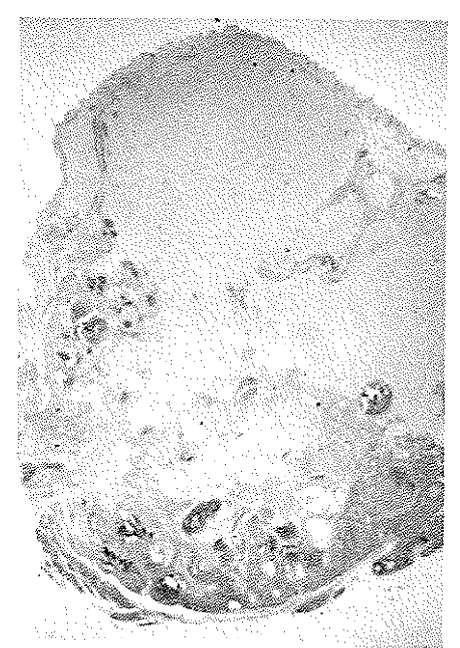

Fig 6

第 6 巻第 3 号 1986 年1月

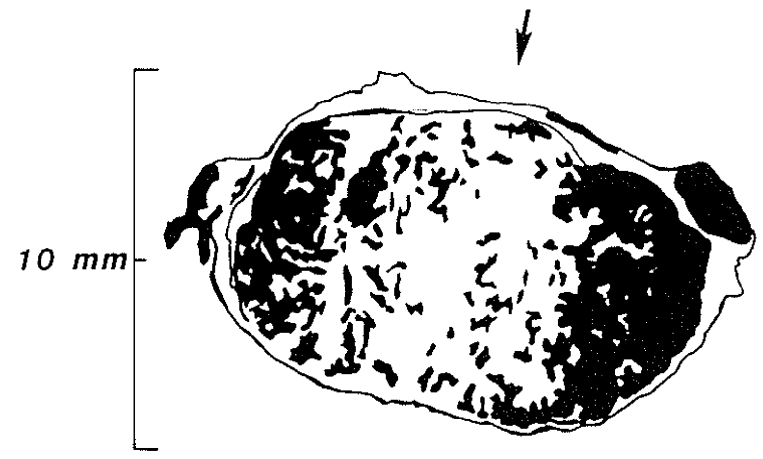

Fig 3

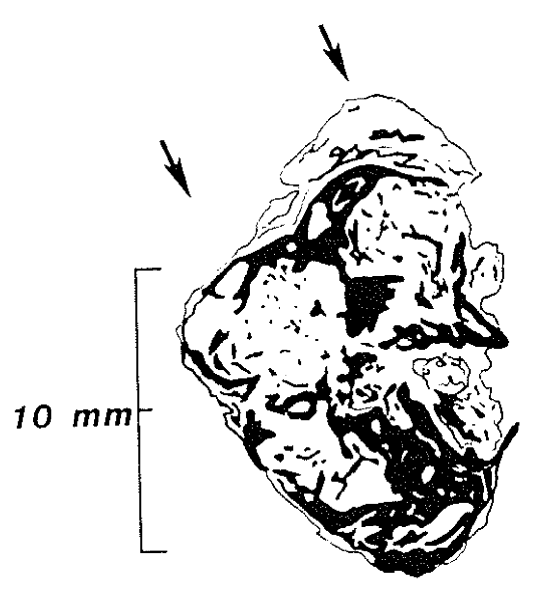

Fig 5

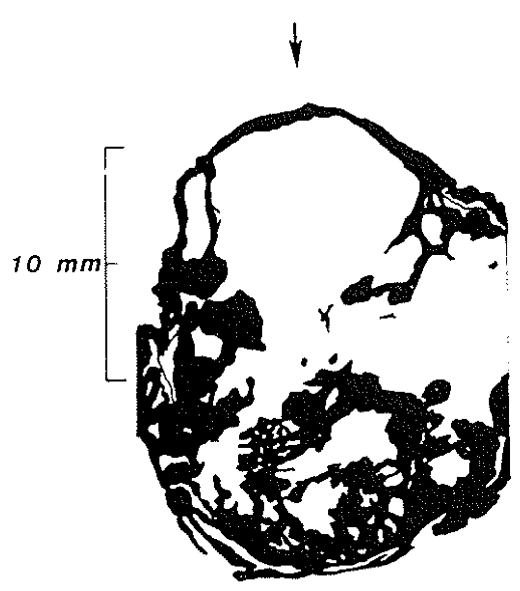

Fig 7 


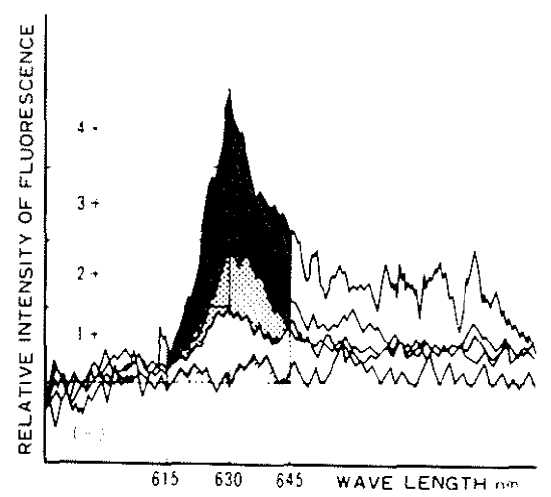

Fig 8

起するのに数フォトンでよいと思われる実験結 果がある事などからみて，一瞬に多くのエネルギ 一を供給できるパルスレーザーは，非常に多くの メリットがあると考党られる。すなわち一瞬に多 くのエネルギーが供給されると, 励起一重項状態 となったHpDが基底状態にもどるわずかな時間の 間に，より深部にある $\mathrm{HpD}$ 分子にェネルギーが届 く為と思动机。

同一条件で行なった実験で，自然発症乳癌に充 分なPDT効果が認められたのにもかかわらず，腫 痬細胞移植マウス腫瘍では，注とんど壊死変化が 認められなかったのは，その厘煌があくまで移植 されたものであり，自然発症乳癌に比べ，栄養血 管の状態など，実際の生体の癌の状態とかなり異 なっている為と思われる。この事は顕微䑰光測光 の結果からも明らかであり， $\mathrm{HpD}$ 効果判定をす る上で，より㥶際の癌の状態に近い自然発症乳癌 等により判定を下さなければならないと思われる。

5. を め

マウス自然発症乳癌に扮いて，エキシマ・ダイ・ レーザーを用いた，パルス光照射によるPDTによ って，最大 $15 \mathrm{~mm}$ ，通常約 $10 \mathrm{~mm}$ に達寸る壊死变化を 認めた。これは，連続光の効果が約 $5 \mathrm{~mm}$ 之言われ てきたのに詨し，明らかにすぐれている。又，照 射周波数の向上により，PDT治療時間の大巾短縮 が可能となる。

\section{文献}

1）大多和正樹：マウス実験廆痬でのエキシマダイ レーザーによるphotodynamic therapy の基整的

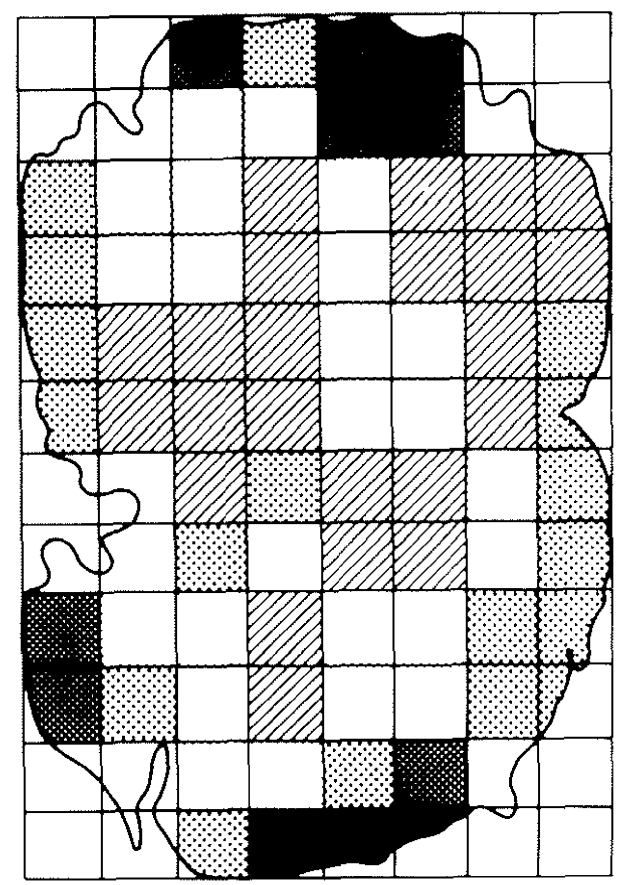

$1 \mathrm{~mm}$

Fig 9

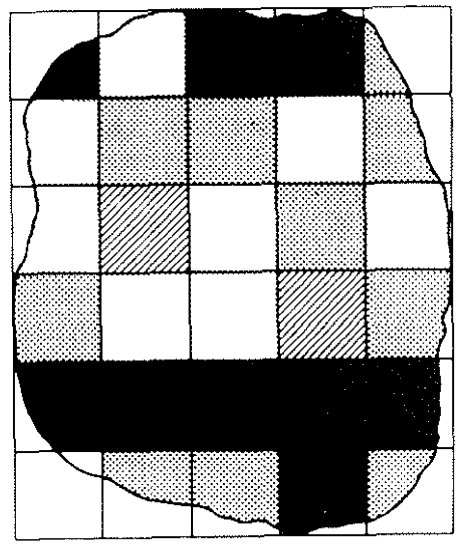

$-1 \mathrm{~mm}$

Fig 10

研究東京医大雑誌 第 43 巻 第 1 号

2）會沢勝夫: HpDを用いたレーザー光化学反応 の基礎：日本レーザー医学会誌 5(4): 3-12，1985

3）加藤治文・他:色素レーザーによる診断と治療 :臨床外科 第 37 巻 第 4 号

4）西宮克明・他:レーザー診断装置を用いたマ ウス移植腫瘍及びマウス臓器に㧍ける $\mathrm{HpD}$ の集積 性の検討:第 43 回日本癌学会総会抄録: 447,1984 